\author{
Bronisław Sitek \\ SWPS University in Warsaw, Poland \\ ORCID: 0000-0002-7365-6954 \\ bsitek@swps.edu.pl
}

\title{
Servus publicus and servus privatus in Ancient Rome: Legal Status and Social Status
}

\author{
Servus publicus a servus privatus w antycznym Rzymie. Status \\ prawny a status społeczny
}

\begin{abstract}
Public slaves were a special group of slaves. As a rule, their legal situation was analogous to private slaves. Hence, there are relatively few preserved sources of law regarding this slave group. There are relatively few Romanist studies regarding the legal situation of public slaves. A larger number of these studies appeared only in the second half of the $20^{\text {th }}$ century. The subject of this study is to compare the legal and social status of both groups of slaves. The purpose is to show a different application of legal provisions depending on their suitability for public matters and the education of public slaves.
\end{abstract}

Keywords: legal status; social status; private slaves; public slaves

\section{INTRODUCTION}

The issue of slavery in ancient Rome was relatively well developed in historical literature, especially in the legal and historical, i.e. in the Romanist literature. The Romanists' greatest interest was related to the legal situation of slaves owned by private persons.

These slaves were used as a labor force to work in the fields (familia rustica) or in cities (familia urbana) to perform various physical, mental and even business 
activities. ${ }^{1}$ In particular, they performed such works as: domestic help, teaching, weaving, crafts, fishing, hunting, construction works, as well as works in the field of medicine, midwives, nursing, mining, accounting. ${ }^{2}$ Due to the place of work, their situation was of course different. The slaves working in cities, especially in Rome, were in a much better position than in the countryside.

The slaves, in the hands of private individuals, were the main driving force for the economy of ancient Rome. ${ }^{3}$ Hence, in the sources of Roman law, we find quite numerous examples containing solving specific cases concerning the treatment or use of slaves for or in performing legal acts. In institutions, which are the contemporary law textbooks, such as the Institutions of Gaius or Justinian, there were mainly decisions regarding the legal position of slaves ${ }^{4}$ legal liability of owners ${ }^{5}$ for their actions, especially legal actions which were performed by slaves on the recommendation or with the knowledge of their owner and how to liberate them. ${ }^{6}$ In turn, the literature contains numerous descriptions of their troubles and woes. ${ }^{7}$

The public slaves were a separate category of slaves. They were employed alongside magistratus of the republican period, in municipalities and at temples, ${ }^{8}$ while during the empire they were employed in the offices of the imperial administration. Most often, they performed their work together with the officials (magistratus) with police powers (coercitio), such as censors or aediles. ${ }^{9}$

Servi publici were not private property, but the property of the Roman people during the republic (populus Romanus), and during the empire they were the property of emperors. Some public slaves were also in the possession of municipal magistratus and in the hands of temple managers. Using modern terminol-

${ }^{1}$ See F. Serrao, Impresa e responsabilità a Roma nell'eta commerciale, Pisa 1989, p. 42 ff.; A. Di Porto, Impresa Collettiva e Schiavo 'Manager' in Roma Antica (II Sec. A.C. - II sec. D.C.), Milan 1984. According to Pomponius, the difference between slaves classified as urbana familia or rustica familia is not in the type but in the place of work. The slave could do the same work in the city, but also in the countryside. See Pumps. L. 6 ad Sab. (D. 50.16.166).

${ }^{2}$ See K. Bradley, Slavery and Society at Rome, Cambridge 1994, pp. 57-80.

${ }^{3}$ See P. Cerami, A. Di Porto, A. Petrucci, Diritto commerciale romano. Profilo storico, Torino 2004, p. $34 \mathrm{ff}$.

${ }^{4}$ G. 1.9 ; I. 1.3.2-4.

${ }^{5}$ Ulp. 29 ad ed. (D. 15.3.5.2). See A.R. Jurewicz, Pater familias dominusve iussit. Umowy zawierane z podległym władzy na podstawie polecenia zwierzchnika, Olsztyn 2015, p. 54 ff.

${ }^{6}$ G. 1.13-29; I. 1.4 pr.-7.

7 The literature message concerns in particular the cases of Romans' cruelty towards slaves (Tac. Hist. 4.11; Svet. Tib. 53). See A. Pawłowska, Sposoby wykonania kary śmierci w relacjach Tacyta i Swetoniusza, „Studia Prawnoustrojowe” 2007, no. 7, p. 80.

${ }^{8}$ Such slaves were often described as servi fanorum or deorum (Varr. De 1.1. 8.41). There were also servi Venerii (Cic. Div. in Caec. 17) or Maritiales (Cic. pro Cluent. 15).

${ }^{9}$ Liv. 43.16; Gell. N.A. 13.13. 
ogy, these slaves did their work for the public apparatus or for municipalities and temples.

The subject of this study is to compare the legal and social position of private (servi privati) and public slaves (servi publici). In turn, the purpose is to show that although the legal position of both categories of slaves was quite similar, their social position differed significantly. In addition, the issues related to public slaves can be used to make discussions and comparisons of the organization of the work of the ancient Rome public apparatus with modern solutions, or how the implementation of public tasks was implemented. It also has to be noticed that the subject of public slaves has been absent in the papers and presentations given during Romanist conferences in Poland for a long time.

\section{LITERATURE ANALYSIS}

At the beginning of the discourse on public slaves, it is worth recalling the scientific achievements on slavery, including public slaves. As has already been mentioned above, the literature on slavery as such is very rich. However, the Romanist research focuses mainly on the issue of private slaves and, as a consequence, it is related to private law issues. The subjects related to public slaves were treated marginally. Only in wider studies, there are some references to public slaves. Larger studies in this area appeared only in the second half of the $20^{\text {th }}$ century.

It should also be noted that what has been written about public slaves, has been synthetically captured relatively long ago by Theodor Mommsen on two pages in the monumental work entitled Römisches Staatsrecht. ${ }^{10}$ And this, what was added later, it was only an extension of his claims based on an in-depth analysis of sources of law, literary sources, inscriptions and papyri.

In the monumental work of William Warwick Buckland, The Roman Law of Slavery: The Condition of the Slave in Private Law from Augustus to Justinian, the issue of public slaves was presented relatively briefly only on twelve pages. ${ }^{11}$ In turn, Olis Robleda, in his work entitled Il diritto degli schavi nell'antica Roma, devoted only four pages to public slaves. ${ }^{12}$ There were also some articles about public slaves, especially during the principate period. ${ }^{13}$

10 Th. Mommsen, Römisches Staatsrecht, vol. 1, Tübingen 1963, pp. 320-321.

11 W.W. Buckland, The Roman Law of Slavery: The Condition of the Slave in Private Law from Augustus to Justinian, Cambridge 1908, pp. 318-330.

12 O. Robleda, Il diritto degli schavi nell'antica Roma, Roma 1976, pp. 64-68.

${ }_{13}$ See A.T. Fear, Cives Latini, servi publici and the Lex Imitana, „Bullettino dell'Istituto do Diritto Romano" 1990, vol. 37, pp. 149-166; J. Menner, Saturninus Servus Publicus. Ein wenig beachtetes Reskript der divi fratres, [in:] Collatio iuris Romani. Fitudes dediees ä Hans Ankum ä l'occasion de 65e anniversaire, ed. R. Feenstra, Amsterdam 1995, pp. 317-330; P.R.C. Weaver, 
Larger studies on public slaves appeared in the second half of the $20^{\text {th }}$ century. These include three monographs. The first is the work of Heinrich Chantraine, Freigelassene und Sklaven im Dienst der römischen Kaiser: Studien zu ihrer Nomenklatur, followed by the work of Walter Eder, Servitus publica, and the newer work by Alexander Weiss, Sklave der Stadt. Untersuchungen zur öffentlichen Sklaverei in den Städten des Römischen Reiches. ${ }^{14}$ Since then, no major study has been written about public slaves. Anyway, it seems that not only the source deposits, but also new research problems have run out. Only, the further exploration of the analysis of existing sources may be done.

When it comes to Polish-language literature on public slaves, two law historians should be mentioned who have dealt with this topic more broadly. In the first place, Iza Bieżuńska-Małowist should be mentioned, who together with her husband Marian Małowist wrote a book entitled The Slavery (Pol. Niewolnictwo). In this book, the whole chapter 5, entitled Slaves in state service (Pol. Niewolnicy w stużbie państwowej), is dedicated to the issue of public slaves. ${ }^{15}$ I. Bieżuńska-Małowist was also interested in slavery in Greece, especially during the Hellenic period. In any case, her achievements in this area were much greater. ${ }^{16}$ In the second place, the study done by Jerzy Kolenda should be mentioned. In 1972, he published an article entitled Imperial slaves and liberators in the administration of the Roman Empire (Pol. Niewolnicy $i$ wyzwoleńcy cesarscy $w$ administracji Imperium Rzymskiego). This author described in his article the classes entrusted to slaves in the office or at the imperial court. ${ }^{17}$ We should also mention the latest Polish-language study done by Karol Kłodziński, titled Officia maxima et princeps officiorum: Research on the Imperial Office of the Principate Period on the Example of the Secretariat a Memoria (Pol. Officia maxima et princeps officiorum. Problematyka badan nad kancelaria cesarska okresu pryncypatu na przyktadzie sekretariatu a memoria).

Imperial slaves and Freedmen in the Brick Industry, „Zeitschrift für Papyrologie und Epigraphik“ 1998, vol. 122, pp. 238-246; idem, The Status Nomenclature of the Imperial Slaves, "The Classical Quarterly” 1964, vol. 14(1), pp. 134-139; A. Nicoletti, ,, Servi publici” e ,, vicarii” in CI 7.9.1, [in:] Sodalitas: scritti in onore di Antonio Guarino, ed. V. Giuffre, vol. 3, Naples 1984, pp. 1483-1487; N. Rouland, A propos des servi publici populi Romani, „Chiron” 1977, vol. 7, pp. 261-278.

${ }_{14}$ H. Chantraine, Freigelassene und Sklaven im Dienst der römischen Kaiser: Studien zu ihrer Nomenklatur, vol. 1, Wiesbaden 1967; W. Eder, Servitus publica, Wiesbaden 1980; A. Weiss, Sklave der Stadt. Untersuchungen zur öffentlichen Sklaverei in den Städten des Römischen Reiches, Stuttgart 2004.

15 I. Bieżuńska-Małowist, M. Małowist, Niewolnictwo, Warszawa 1987, pp. 129-144.

${ }^{16}$ I. Bieżunska-Małowist, Les esclaves impériaux dans l'Egypte romaine, Schiavitù, manumissione e classi disponendi nel mondo, Roma 1979, pp. 175-183; eadem, Les esclaves en copropriété dans l'Egypte gréco-romaine, „Aegyptus Rivista italiana di egittologia e di papirologiat” 1968,

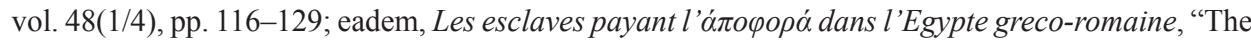
Journal of Juristic Papyrology" 1965, vol. 15, pp. 65-72.

17 J. Kolenda, Niewolnicy $i$ wyzwoleńcy cesarscy w administracji Imperium Rzymskiego, „Kwartalnik Historyczny" 1972, no. 2, pp. 361-365. 
This author, an employee of the Nicolaus Copernicus University library, has a lot more studies dedicated to the organization and functioning of the imperial administration. $^{18}$

\section{SOME STATISTICS}

The statistical data on the size of the slave population, including public slaves, in relation to the entire population of the Empire, or at least to the population of Italy may be an interesting issue for the modern reader. It must be stated at the very beginning that the number of public slaves was significantly lower than the number of private slaves. Based on preserved sources, it is difficult to estimate the total number of slaves that was in the space from the time of founding of Rome to the time of Justinian. The more accurate data which has been preserved, most often refer to the micro-scale. And so, Galen (Clausius Galenus), a Roman physician living between 130 and 200, wrote that in Pergamon, there were about 40,000 citizens (men) and 80,000 women and slaves including children. ${ }^{19}$ However, this message does not show the final number of slaves, including public slaves.

In order to illustrate what numbers can be referred to in relation to the size of the slave population, reference should be made to estimates, the calculations of which were made, among others by Peter A. Brunt. ${ }^{20}$ According to him, around 7.5 million inhabitants (men and women) and around 3 million slaves lived in Italy at the end of the republic period. According to Julius Beloch, in Rome during the census in 5 B.C., there were around 500,000 citizens, 70,000 peregrines, mainly from Greece, and about 280,000 slaves. In total, at the beginning of the principate, Rome had about 850,000 residents. ${ }^{21}$ Therefore, it is assumed in the literature that since the end of the republic, the share of slaves in the structure of society has been at the

${ }^{18}$ K. Kłodziński, Officia maxima et principes officiorum. Problematyka badań nad kancelaria cesarska okresu pryncypatu na przyktadzie sekretariatu a memoria, Kraków 2012. See also idem, Sekretarze ab epistulis ia libellis w kancelarii cesarzy od Augusta do Hadriana. Studium historyczno-prawne, Torun 2011; idem, Udziat sekretarzy ab epistulis ia libellis w procesie tworzenia reskryptów cesarskich, „Studia Iuridica Toruninsia” 2011, vol. 8, pp. 48-67; idem, The office of 'a rationibus' in the imperial government: A historiographical controversy, „Eos. Commentarii Societatis Philologae Polonorum" 2015, vol. 102(1), pp. 95-128.

19 Galen 5.47.

${ }^{20}$ P.A. Brunt, Italian Manpower 225 B.C.-A.D. 14, Oxford 1971, p. 124, as it is in: W. Scheidel, The Slave Population of Roman Italy. Speculation and Constraints, "Topoi Orinet-Occident" 1999, vol. 9(1), pp. 129-144.

${ }^{21}$ The number of slaves depended mainly on needs. A larger number of slaves were in those cities where manufactories or crafts were well developed. In Rome, slaves were most often a service to wealthier citizens. See J. Beloch, Die Bevölkerung der griechisch-römischen Welt, Leipzig 1886, p. 404 . 
level of around $35 \% .{ }^{22}$ Of course, in individual provinces or cities, these numbers could sometimes differ significantly. This state of the demographic structure of Roman society also persisted during the late Empire.

An analysis of Romanist literature indicates that so far no attempt has been made to analyze sources in terms of determining even an approximate number of public slaves in the Roman empire, at least divided into basic political periods such as the republic, principate or dominate. Such statistics were also not carried out in studies on the Roman population, including by the work of Julis Beloch ${ }^{23}$ or Keith Bradley. ${ }^{24}$ It is also unclear whether such an analysis would be possible. Figures about public slaves in sources of law or in literary sources are mentioned occasionally. Some mentions can be found, among others, the information about 500 slaves working to repair public buildings in Rome or about 3,000 slaves working in a temple in Antioch. ${ }^{25}$

\section{LEGAL SITUATION OF PRIVATE AND PUBLIC SLAVES}

The position of the law of Roman slaves must be analyzed in the context of philosophical conditions which undoubtedly had an impact on specific legal solutions.

Florent. L. 9 Inst. (D. 1.5.4.pr.-1): pr. Libertas est naturalis facultas eius quod cuique facere libet, nisi si quid vi aut iure prohibetur. 1. Servitus est constitutio iuris gentium, qua quis dominio alieno contra naturam subicitur.

Florentinus, a Roman lawyer living in the Antonin times, conveyed a fundamental conviction for those times that all people are born free. It is only on the basis of ius gentium that people are divided into free and slaves. ${ }^{26}$ Freedom is the natural quality of human being who flows from ius naturale..$^{27}$ According to Sebastiano Tafaro, the Romans were aware that there is a conflict between the natural order of things and law, which is reflected in slavery. ${ }^{28}$

${ }^{22}$ See W. Scheidel, The Slave Population..., p. 134.

${ }^{23}$ See J. Beloch, op. cit.

${ }^{24} \mathrm{~K}$. Bradley, op. cit., pp. $10 \mathrm{ff}$.

${ }^{25}$ See W. Scheidel, Slavery in the Roman economy, www.princeton.edu/ pswpc/pdfs/ scheidel/091003.pdf [access: 11.09.2019], p. 4. At Pliny the Elder in N.H. 33.135 there is a description of the property of the ex-consul, who owned over 4,000 slaves, whom he probably used for public works in his office. In turn, Tacitus in Ann. 14.43 describes the story of a consul being killed by one of his slaves. Consequently, 400 slaves were to be punished. Such a severe punishment aroused social discussion over its purposefulness and to such an extent that the matter was dealt with by the Roman Senate.

${ }^{26}$ Ulp. 1 Inst. (D. 1.1.4. pr.).

${ }^{27}$ Ulp. L. 43 ad Sab. (D. 50.17.32); I. 1.3.pr.

28 S. Tafaro, Ius hominum causa constitutum. Un derecho a medida del hombre, Madrid 2014, p. 199. 
These ontological messages allow us to understand some differences which exist in normative regulations regarding things in the sense of material objects from regulations regarding slaves also belonging to the res category. These views, however, did not exclude the fundamental definition of the legal position of slaves, which is servitude (servitus) is an institution of the law of nations consisting in the fact that someone has to bear the authority of another person against his or her nature. ${ }^{29}$ This legal situation did not change even when legal provisions were introduced which aimed at more humane treatment of sick slaves ${ }^{30}$ or the ban of abuse of slaves. ${ }^{31}$ The slave still remained a thing and according to Palus, he had no rights - nullum ius habet..$^{32}$ Since the slaves had no rights, it means they had no legal capacity and the capacity to legal actions; they could not incur any obligations: In personam servilem nulla cadit obligatio. ${ }^{33}$

In conclusion, it can be stated that the slave, as a thing, could not perform any civil law binding legal actions or hold public offices. However, he could conclude contracts on behalf of his owner. ${ }^{34}$ At that time, the slave was not obliged, but his owner. Consequently, slaves could not be soldiers in Roman legions, ${ }^{35}$ they could not hold the office of a decurion, ${ }^{36}$ or take other high public offices. Instead, they could be used in the performance of works carried out in the framework of even high public offices. ${ }^{37}$

The legal status of public and private slaves was in principle the same. Both, in the legal system, held the status of things. Consequently, the sources of Roman law do not contain any work done by prudentes which would be dedicated solely to public slaves - servi publici Populi Romani. This was due to the fact that their legal situation was analogous to slaves in private hands. Thus, public slaves were treated as a thing, even if their social position was sometimes comparable to even free people - and this will be discussed later. Consequently, the public slaves could therefore be sold, ${ }^{38}$ bought, ${ }^{39}$

${ }^{29}$ I. 1.3.2; Florent. 9 Inst. (D. 1.5.4.1); Tryph. L. 7 disp. (D. 12.6.64).

${ }^{30}$ G. 1.53 .

31 See F. Longchamps de Bérier, Dwie konstytucje Antonina Piusa zakazujące srożenia się nad niewolnikami, [in:] Crimina et mores. Prawo karne w starożytnym Rzymie, ed. M. Kuryłowicz, Lublin 2001, pp. 89-99.

32 Paul. 11 ad. Ed. (D. 4.5.3.1).

${ }^{33}$ Ulp. L. 28 ad Sab. (D. 50.17.22.pr.).

${ }^{34}$ I. 4.7.1.

35 Plin. ep. 30.

36 C. 10.38 .

${ }^{37}$ Paul. 69 ad ed. (D. 2.11.7); Paul. 69 ad ed. (D. 50.17.211).

${ }^{38}$ Ulp. L. 6 ad disput. (D. 40.1.4.8).

39 App. 1.100. 
given ${ }^{40}$ or transferred by inheritance,$^{41}$ but public slaves could also be liberated. The private slave and his family belonged to the property of the owner. ${ }^{42}$ The public slave was the property of the state, emperor, municipium or temple at which he served.

\section{THE SOCIAL SITUATION OF PRIVATE AND PUBLIC SLAVES}

Unlike the legal situation of both groups of slaves, which was very similar or even identical, their social position looked completely different. Private slaves most often performed servicing work in farming or helped in running a household in the city. The slave labor force was used most often by richer social strata. The severe fate of private slaves has been the subject of numerous communications from ancient authors, which in modern times has become an inspiration for fiction literature or film art, such as Spartacus (1960), The Eagle (2011) or Gladiator (2000).

Private slaves usually did not have to have any special training or education to perform simple jobs. However, one should not forget about the group of highly qualified slaves entrusted with the management of private landed estates, shops, warehouses and the management of a seagoing ship. Sometimes, slave's children were educated in the context of scheduled activities that were to be entrusted to them in the future. ${ }^{43}$

On the other hand, the public slaves were mostly highly qualified. Hence the concept of servus publicus populi Romani is not only a matter of ownership, but above all, the matter of tasks they performed for the public community. ${ }^{44}$ Most often, they became slaves precisely because they had education and they were well prepared to practice a specific profession. They were mostly craftsmen, mathematicians, financiers, managers, ship captains, public administration employees and architects who practiced their professions before they lost their freedom or were trained to practice. The confirmation of the difference in the education of both

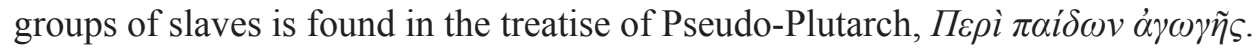
The author of this work is surprised that the best slaves are devoted to the public

${ }^{40}$ Liv. $22.57 .11 ; 27.4 ; 32.26 .14$.

${ }^{41}$ Augustus gave to the State the slaves who paid for waterworks, whose he received in a last will from Agrippa (Frontonius de aequed. c. 98.11).

${ }^{42}$ Ulp. L. 20 ad Sab. (D. 33.7.12.33): Contubernales quoque servorum, id est uxores, et natos, instructo fundo contineri verum est. See. E. Polay, Il matrimonio degli schiavi nella Roma repubblicana, Torino 1970, pp. 77-99; B. Sitek, Mediacja szansa na ocalenie matżeństwa? Studium prawa rzymskiego, kanonicznego i cywilnego, "Journal of Modern Science" 2017, vol. 32(1), pp. 113-131.

${ }^{43}$ B. Sitek, Stosowanie kary chłosty jak środka dydaktycznego w antycznym Rzymie. Współczesne refleksje, [in:] Przemoc w świetle starożytnym. Źródła - struktura - interpretacja, eds. D. Słapek, I. Łuć, Lublin 2017, pp. 333-349; S.F. Bonner, Education in Ancient Rome: From the Elder Cato to the Younger Pliny, London 2012, p. 36.

${ }^{44}$ Liv. 26.47. 
service and the education of children is entrusted to drunkards and gluttons. According to the author of this treatise, the ideal teacher was Phoenix, the teacher of Achilles. ${ }^{45}$

During the republic period, servi publici performed their work at various $m a-$ gistratus entrusted with overseeing the implementation of public works. They were mainly censors and aediles, under whose supervision slaves worked on the construction or repair of aqueducts, public roads, fire fighting, or in public libraries. From the beginning of the principate period, the public slaves are met with imperial officials who support them in performing the public tasks entrusted to them. ${ }^{46}$ Already during the reign of the Julian-Claudian dynasty emperors, slaves or freedmen were employed at many public offices. The slaves carried out their work most often under the direction of civilian officials. ${ }^{47}$ During the reign of Emperor Hadrian, slaves also worked in the secretariats of the imperial office. An example would be the secretariat a commentariis, in which imperial documents were registered. ${ }^{48} \mathrm{~K}$. Kłodziński emphasizes that sometimes it is quite difficult to distinguish whether a particular job was performed by a slave or a freedman.

An analysis of sources, especially inscriptions, shows that the majority of slaves worked in the public finance sector, both in Rome and in the province. At the head of the local treasury, there were mostly freedmen, but also slaves - dispensatores. The position of such slave was very strong. This is evidenced by the fact that he had his own slaves referred to as vicarii. Most often they were highly qualified. The position of dispensatores, de facto, a state official, is evidenced by the composition of his slave team. They were people who knew about accounting and finance, but there were also doctors, chefs and butlers. ${ }^{49}$

The analysis of the sources of Roman law in terms of the legal and social situation of public slaves shows that fairly strict laws regarding private slaves did not always bind public slaves, at least not to the same extent.

This difference in the social situation of public slaves compared to ordinary - private slaves was manifested, i.a., in their family situation. Under Roman law, slave relationships between a slave-men and the slave-women were referred to as contubernium and were not recognized by ius civile, so they did not have the status of matrimonium iustum. The relationships of slave-men with free women who did

${ }^{45}$ A critical discussion of this text is in P. Madejski, Księdza Józefa Rokosznego przekład traktatu

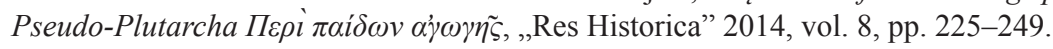

${ }^{46}$ From the available sources it appears that Augustus already used the services of slaves, performing specific tasks in the imperial palace (CIL VI 8596). See K. Kłodziński, Officia maxima..., p. 25.

${ }^{47}$ See ibidem, p. 11.

48 Ibidem, pp. 126-127.

${ }^{49}$ See I. Bieżuńska-Małowist, M. Małowist, op. cit., p. 139. 
not own them were banned. ${ }^{50}$ The sanction for the woman for such a relationship was capitis deminutia maxima - it means the loss of freedom. This sanction was not a manifestation of concern for the state of public morality, but a consequence of violation of someone else's property without the consent of the owner. ${ }^{51}$ Thus, it was permissible for a free woman to have her own slave. ${ }^{52}$

In the case of public slaves, they had a relationship with free women. Often, these relationships were permanent, similar to the marriage of free people with a conubium. These relations were not banned and we can repeat here after Th. Mommsen that they were quasi-marriages - Quasi-Ehe. Such relationships occurred primarily in the case of slaves holding high positions in public administration. Children born from such relations were free and received their mother's surname or family name. ${ }^{53}$

Finally, the special situation of a public slave is also evidenced by the possibility of disposing of his own financial means, in a completely different way than in the case of entrusting private property in the form of peculium to a private slave. A public slave could freely dispose of half of his property acquired while holding public offices. Such a conclusion in Romanist literature is built on the basis of a fragment derived from Ulpian's rules. ${ }^{54}$

Regulae Ulpiani 20.16: Servus publicus populi Romani partis dimidiae testamenti faciendi habet ius. ${ }^{55}$

According to the literal wording of the above text, it can be concluded that a public slave could have allocated half of his property in a last will. Therefore, he would have a testamenti facultas activa. However, in some Romanist literature there is a discussion about the authenticity of such a solution. It is contrary to dogma in this respect and is not confirmed by other sources, especially in Digests. It should therefore be assumed that the text derived from Ulpian's rules is not authentic and was written much later. In Justinian's time, the public slave could not

50 Th. Mommsen, op. cit., p. 324.

51 This ban only applied to Roman women and Latin women. It did not bind women of other citizenship. This ban was introduced on the basis of s.c. Claudianum from 54 B.C. (Pauli Sent. 2.21a.1; $6 ; 11)$.

52 See J.M. Rainer, Corpus der Römischen Rechtsquellen zur Antiken Sklaverei, vol. 1: Die Begründung des Sklavenstatus nach ius gentium und ius civile, Stuttgart 1999, p. $20 \mathrm{ff}$.

${ }^{53}$ In CIL VI 2310 there is a tombstone inscription that someone is a son of publicus Xviralis. See Th. Mommsen, op. cit., p. 324; G. Boulvert, Esclaves et affranchis impériaux sous te Haut Empire romain. Role politique et adm inistratif, Neapol 1970; idem, Domestique et fonctionnaire sous le Haut Empire romain: La condition de l'affranchi et de l'esclavage du prince, Paris 1974; P.R.C. Weaver, Familia Caesaris: A Social Study of the Emperor's Freedmen and Slaves, Cambridge 1972.

${ }^{54}$ Ulpiani liber singularis regularum, transl. and explanations A. Dębiński, K. Burczak, Lublin 2016.

55 Analogously see Plin. ep. 8.16. 
inherit, as did the private slave. However, it cannot be ruled out that the slave may have disposed of his property in some way in the event of his death, for example by the donation, which may have been considered by some as a possibility of the testamentary ability. ${ }^{56}$

Finally, it should be added that public slaves wore appropriate outfits that made them stand out on the street. They usually wore a tunic, which had to be girded at the level of the navel with a string - limo cincti $^{57}$ Rather, the slaves were not allowed to walk in gowns alone. ${ }^{58}$ Such clothes were worn by, among others, the slaves working at the side of the Aediles - cum cincto limo, hence they were called as limocincti. ${ }^{59}$

\section{CONCLUSIONS}

The issue of slavery in ancient Rome has enjoyed great interest from Romanists for a long time. The main subject of the study was the analysis of legal provisions regarding the legal situation, in particular the legal situation of the private slaves. A lot of books and articles have been created in this area since the end of the $19^{\text {th }}$ century. Among them, there are also some studies done by the Polish Romanists or law historians, especially by Iza Bieżuńska-Małowist.

A group of public slaves remained hardly noticeable to researchers for a long time, Those slaves were employed to help with republican, municipal, temple and later imperial offices. Legally, their status was the same as private slaves. As a thing, they were deprived of legal personality and they could be sold, bought or liberated.

However, while comparing the social position of both groups of slaves, one can see significant differences between them in favor of public slaves. The private slaves usually performed simple tasks for which they did not have to be highly qualified. Only some of them had higher qualifications when practicing as teachers or property managers. On the other hand, in the case of public slaves, as per rule, they were highly qualified. Sources contain numerous cases of public slaves

${ }^{56}$ See A. Wagner, Die soziale Entwicklung des Sklavenrechts in der römischen Kaiserzeit. Insbesondere auf Grund des Codex Iustinianes, Marburg 1968, p. 84.

57 The distinctive outfit of public slaves is mentioned in municipal laws, for example in lex Ursonensis cap. 62 and in lex Irnitana cap. 19. See C.F. Norena, N. Papazarkadas, From Document to History: Epigraphic Insights into the Greco-Roman World, Leiden-Boston 2019, pp. 280-281; B. Sitek, Lex Coloniae Genetivae Iuliae seu Ursonensis i lex Irnitana. Ustawy municypalne antycznego Rzymu. Tekst, ttumaczenie i komentarz, Poznań 2008, pp. 24-27, 93-95. See also Gell. 12.33.

${ }^{58}$ On one tombstone inscription of a public slave, he was depicted wearing the toga itself (CIL VI 2365).

59 See A. Weiss, Limocincti in Irni. Zur Erganzug dess Duumvir paragraphen 18 der Lex Irnitana, „Zeitschrift für Papyrologie und Epigraphik“ 2001, vol. 135, pp. 284-286. 
who worked at offices and have gained considerable wealth. This group of slaves was not affected by very restrictive regulations prohibiting relationships with free women. In addition, only men were public slaves. Women were also private slaves.

To conclude this study, it should be noted that in ancient times, due to the usefulness of a particular person, there could be a gap between legal and social status. From a legal point of view, all slaves had the same legal status. However, due to the greater utility of public slaves, numerous legal norms were suspended. Such a conclusion allows us to explain also the modern phenomenon related to the application of the constitutional principle of equality of all people before the law. In reality, however, from a social point of view, differences between individuals or groups of people can be significant.

\section{REFERENCES}

Beloch J., Die Bevölkerung der griechisch-römischen Welt, Leipzig 1886.

Bieżunska-Małowist I., Les esclaves en copropriété dans l'Egypte gréco-romaine, „Aegyptus Rivista italiana di egittologia e di papirologiat" 1968, vol. 48(1/4).

Bieżunska-Małowist I., Les esclaves impériaux dans l'Egypte romaine, Schiavitù, manumissione e classi disponendi nel mondo, Roma 1979.

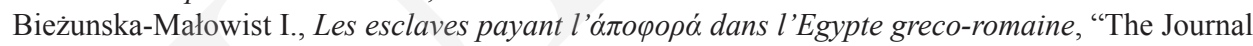
of Juristic Papyrology" 1965, vol. 15.

Bieżuńska-Małowist I., Małowist M., Niewolnictwo, Warszawa 1987.

Bonner S.F., Education in Ancient Rome: From the Elder Cato to the Younger Pliny, London 2012.

Boulvert G., Domestique et fonctionnaire sous le Haut Empire romain: La condition de l'affranchi et de l'esclavage du prince, Paris 1974.

Boulvert G., Esclaves et affranchis impériaux sous te Haut Empire romain. Role politique et adm inistratif, Neapol 1970.

Bradley K., Slavery and Society at Rome, Cambridge 1994.

Brunt P.A., Italian Manpower 225 B.C.-A.D. 14, Oxford 1971.

Buckland W.W., The Roman Law of Slavery: The Condition of the Slave in Private Law from Augustus to Justinian, Cambridge 1908

Chantraine H., Freigelassene und Sklaven im Dienst der römischen Kaiser: Studien zu ihrer Nomenklatur, vol. 1, Wiesbaden 1967.

Cerami P., Di Porto A., Petrucci A., Diritto commerciale romano. Profilo storico, Torino 2004.

Di Porto A., Impresa Collettiva e Schiavo 'Manager' in Roma Antica (II Sec. A.C. - II sec. D.C.), Milan 1984.

Eder W., Servitus publica, Wiesbaden 1980.

Fear A.T., Cives Latini, servi publici and the Lex Imitana, „Bullettino dell'Istituto do Diritto Romano” 1990, vol. 37.

Jurewicz A.R., Pater familias dominusve iussit. Umowy zawierane z podległym władzy na podstawie polecenia zwierzchnika, Olsztyn 2015.

Kłodziński K., Officia maxima et principes officiorum. Problematyka badań nad kancelaria cesarska okresu pryncypatu na przyktadzie sekretariatu a memoria, Kraków 2012.

Kłodziński K., Sekretarze ab epistulis ia libellis w kancelarii cesarzy od Augusta do Hadriana. Studium historyczno-prawne, Torun 2011. 
Kłodziński K., The office of 'a rationibus' in the imperial government: A historiographical controversy, „Eos. Commentarii Societatis Philologae Polonorum” 2015, vol. 102.

Kłodziński K., Udziat sekretarzy ab epistulis ia libellis w procesie tworzenia reskryptów cesarskich, „Studia Iuridica Toruninsia” 2011, vol. 8, DOI: https://doi.org/10.12775/SIT.2011.003.

Kolenda J., Niewolnicy $i$ wyzwoleńcy cesarscy $w$ administracji Imperium Rzymskiego, „Kwartalnik Historyczny" 1972, no. 2.

Longchamps de Bérier F., Dwie konstytucje Antonina Piusa zakazujące srożenia się nad niewolnikami, [in:] Crimina et mores. Prawo karne w starożytnym Rzymie, ed. M. Kuryłowicz, Lublin 2001.

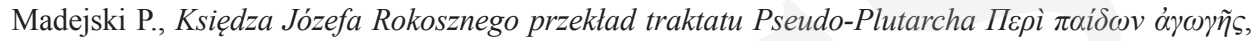
„Res Historica” 2014, vol. 8.

Menner J., Saturninus Servus Publicus. Ein wenig beachtetes Reskript der divi fratres, [in:] Collatio iuris Romani. Fitudes dediees ä Hans Ankum ä l'occasion de 65e anniversaire, ed. R. Feenstra, Amsterdam 1995.

Mommsen Th., Römisches Staatsrecht, vol. 1, Tübingen 1963.

Nicoletti A., ,, Servi publici” e ,, vicarii” in CI 7.9.1, [in:] Sodalitas: scritti in onore di Antonio Guarino, ed. V. Giuffre, vol. 3, Naples 1984.

Norena C.F., Papazarkadas N., From Document to History: Epigraphic Insights into the Greco-Roman World, Leiden-Boston 2019.

Pawłowska A., Sposoby wykonania kary śmierci w relacjach Tacyta i Swetoniusza, „Studia Prawnoustrojowe" 2007, no. 7.

Polay E., Il matrimonio degli schiavi nella Roma repubblicana, Torino 1970.

Rainer J.M., Corpus der Römischen Rechtsquellen zur Antiken Sklaverei, vol. 1: Die Begründung des Sklavenstatus nach ius gentium und ius civile, Stuttgart 1999.

Robleda O., Il diritto degli schavi nell'antica Roma, Roma 1976.

Rouland N., A propos des servi publici populi Romani, „Chiron” 1977, vol. 7.

Scheidel W., Slavery in the Roman economy, www.princeton.edu/ pswpc/pdfs/scheidel/091003.pdf [access: 11.09.2019].

Scheidel W., The Slave Population of Roman Italy. Speculation and Constraints, "Topoi Orinet-Occident" 1999, vol. 9(1), DOI: https://doi.org/10.3406/topoi.1999.1808.

Serrao F., Impresa e responsabilità a Roma nell'eta commerciale, Pisa 1989.

Sitek B., Lex Coloniae Genetivae Iuliae seu Ursonensis i lex Irnitana. Ustawy municypalne antycznego Rzymu. Tekst, thumaczenie i komentarz, Poznań 2008.

Sitek B., Mediacja szansa na ocalenie matżeństwa? Studium prawa rzymskiego, kanonicznego i cywilnego, "Journal of Modern Science" 2017, vol. 32(1).

Sitek B. Stosowanie kary chłosty jak środka dydaktycznego w antycznym Rzymie. Wspótczesne refleksje, [in:] Przemoc w świetle starożytnym. Źródła - struktura - interpretacja, eds. D. Słapek, I. Łuć, Lublin 2017.

Tafaro S., Ius hominum causa constitutum. Un derecho a medida del hombre, Madrid 2014.

Ulpiani liber singularis regularum, transl. and explanations A. Dębiński, K. Burczak, Lublin 2016.

Wagner A., Die soziale Entwicklung des Sklavenrechts in der römischen Kaiserzeit. Insbesondere auf Grund des Codex Iustinianes, Marburg 1968.

Weaver P.R.C., Familia Caesaris: A Social Study of the Emperor's Freedmen and Slaves, Cambridge 1972.

Weaver P.R.C., Imperial slaves and Freedmen in the Brick Industry, „Zeitschrift für Papyrologie und Epigraphik“ 1998, vol. 122.

Weaver P.R.C., The Status Nomenclature of the Imperial Slaves, “The Classical Quarterly" 1964, vol. 14(1), DOI: https://doi.org/10.1017/S0009838800008612.

Weiss A., Limocincti in Irni. Zur Erganzug dess Duumvir paragraphen 18 der Lex Irnitana, „Zeitschrift für Papyrologie und Epigraphik“" 2001, vol. 135.

Weiss A., Sklave der Stadt. Untersuchungen zur öffentlichen Sklaverei in den Städten des Römischen Reiches, Stuttgart 2004. 
Pobrane z czasopisma Studia Iuridica Lublinensia http://studiaiuridica.umes.pl Data: 26/04/2023 07:08:51

\begin{abstract}
ABSTRAKT
Szczególną grupą niewolników byli niewolnicy publiczni. Co do zasady ich sytuacja prawna była analogiczna do niewolników prywatnych. Stąd też jest stosunkowo mało zachowanych źródeł prawa dotyczących tej grupy niewolniczej. Niewiele jest opracowań romanistycznych dotyczących sytuacji prawnej niewolników publicznych. Więcej tych opracowań pojawiło się dopiero w drugiej połowie XX w. Przedmiotem niniejszego opracowania jest porównanie statusu prawnego i społecznego obu grup niewolników. Celem jest ukazanie odmiennego stosowania przepisów prawa w uzależnieniu od przydatności dla spraw publicznych oraz wykształcenia niewolników publicznych.
\end{abstract}

Słowa kluczowe: status prawny; status społeczny; niewolnicy prywatni; niewolnicy publiczni 